\title{
Literature Review : Pengaruh Teknik Pernapasan Buteyko Terhadap Kontrol Asma
}

\author{
Novi Andriyani ${ }^{1 *}$, Dian Kartikasari ${ }^{2}$ \\ 1,2 Program Studi Sarjana Keperawatan, Universitas Muhammadiyah Pekajangan Pekalongan, \\ Indonesia \\ *email: noviandriyani99@gmail.com
}

\begin{abstract}
The Backgrounds : Asthma can cause narrowing of the airways, and it can cause symptoms such as wheezing, coughing, and shortness of breath (dyspnea), therefore treatment is needed to control asthma to reduce the symptoms caused. One of the nonfarmacological treatments is using the buteyko breathing technique. To describe the effect of the buteyko breathing technique on asthma control. This literature review research accessed the Garba Garuda and Researchgate databases. Search articles using two languages, for Indonesian-language articles, the search was conducted using the keywords: "Asma", "Buteyko", "Kontrol asma", while the English-language articles used the keywords: "Asthma", "Buteyko", "Asthma control". This study used the JBI critical appraisal checklist for quasiexperimental studies, and the PICOTS format (population, intervention, comparative group, outcome, time, study design) in determining inclusion and exclusion criteria. The results of this literature review showed that there was an increase in the level of asthma control after the intervention. There was also an effect of giving the buteyko breathing technique on asthma control. The $p$-value was less than 0.05 . The conclusion of this literature review research showed that there was an effect of giving the buteyko breathing technique on asthma control.
\end{abstract}

Keywords : Asthma; Buteyko; Asthma control

\begin{abstract}
Abstrak
Penyakit asma dapat menyebabkan penyempitan pada saluran napas, dan hal ini dapat menimbulkan gejala seperti mengi, batuk, dan sesak napas (dispnea) pada penderitanya, maka dari itu diperlukan pengobatan untuk mengontrol asma agar mengurangi gejala yang ditimbulkan. Salah satu pengobatan non farmakologinya yaitu dengan menggunakan teknik pernapasan buteyko. Tujuan dari penelitian literature review ini adalah untuk mengetahui pengaruh teknik pernapasan buteyko terhadap kontrol asma.

Penelitian literature review ini mengakses database Garba Garuda, dan Researchgate. Pencarian artikel menggunakan dua bahasa yaitu bahasa Indonesia, dan bahasa Inggris, untuk artikel berbahasa Indonesia, pencarian dilakukan dengan menggunakan kata kunci : "Asma", "Buteyko", "Kontrol Asma", sedangkan artikel berbahasa Inggris menggunakan kata kunci : "Asthma", "Buteyko", "Asthma control". Instrumen telaah kritis yang digunakan yaitu dengan menggunakan JBI critical appraisal checklist for quasi-eksperimental studies, serta menggunakan format PICOTS (population, intervention, comparative group, outcome, time, studi design) dalam menentukan kriteria inklusi dan eksklusi. Hasil penelitian literature review ini menunjukkan bahwa terdapat kenaikan pada tingkat kontrol asma sesudah pemberian intervensi tersebut, dibandingkan sebelum pemberian intervensi, dan terdapat pengaruh pemberian teknik pernapasan buteyko dengan kontrol asma dengan hasil $\mathrm{p}$ value $<0,05$. Simpulan dari penelitian literature review ini menunjukkan bahwa terdapat pengaruh pemberian teknik pernapasan buteyko terhadap kontrol asma.
\end{abstract}

Kata Kunci : Asma; Buteyko; Kontrol asma 


\section{Prosiding Seminar Nasional Kesehatan 2021 Lembaga Penelitian dan Pengabdian Masyarakat Universitas Muhammadiyah Pekajangan Pekalongan}

\section{Pendahuluan}

Asma adalah penyakit pada sistem respirasi yang mengalami penyempitan, akibat dari hiperaktivitas terhadap rangsangan tertentu yang mengakibatkan timbulnya peradangan atau inflamasi [1]. Siswanti [2] menyatakan bahwa asma merupakan penyakit inflamasi kronik saluran napas yang dapat menyebabkan meningkatnya hiperresponsif pada jalan nafas, gejalanya dapat berupa mengi, sesak napas, dada terasa berat dan batuk terutama pada malam menjelang dini hari.

Global Initiative For Asthma [3] menyatakan bahwa sekitar 300 juta orang didunia mengidap asma dan World Health Organization (WHO) memperkirakan bahwa pada tahun 2025 pengidap asma akan mencapai 400 juta [4]. Di Amerika Serikat, telah dilakukan survey oleh National Health Interview yang memperkirakan bahwa terdapat 7,5 juta orang penduduk negara Amerika Serikat mengalami bronkitis kronik, lebih dari dua juta orang mengalami emfisema dan 6,5 juta orang mengalami penyakit asma. Berdasarkan GINA tahun 2016, prevalensi asma di Asia Tenggara sebesar 3,3\% (sebanyak 17,5 juta orang menderita asma dari 529,3 juta total populasi), sedangkan di Indonesia merupakan penyakit saluran napas kronik yang menjadi masalah serius untuk kesehatan masyarakat [5]. Penyakit asma merupakan peringkat sepuluh besar dari penyakit pemicu morbiditas dan mortalitas [6]. Peningkatan jumlah tersebut ditimbulkan karena asma merupakan penyakit yang tidak terdiagnosis dan buruknya kontrol asma [4].

Pengendalian atau kontrol asma sangat diperlukan untuk mengatasi gejalanya. Tujuan utama dari kontrol/pengendalian asma yaitu untuk mengontrol manifestasi klinis dari penyakit untuk waktu yang lama, meningkatkan dan mempertahankan kualitas hidup agar penderita asma dapat hidup normal tanpa hambatan melakukan aktivitas setiap harinya [4]. Secara umum, terdapat dua pengobatan yang bisa digunakan oleh penderita asma yaitu dengan menggunakan terapi farmakologis dan terapi non farmakologis. Terapi non farmakologis yang bisa digunakan pada penderita asma diantaranya yaitu dengan berhenti merokok, diet sehat, menghindari alergen, mengurangi aktifitas berat, menurunkan berat badan, menghindari polusi, vaksinasi, mengurangi stres, menghindari makanan dan bahan kimia yang menyebabkan alergi, serta menjaga kebugaran seperti physical activity dan breathing exercise [7]. Teknikteknik seperti ini merupakan teknik yang banyak dikembangkan oleh para ahli. Salah satu teknik yang banyak digunakan dan mulai populer adalah teknik pernapasan [8].

Teknik pernapasan adalah teknik memberdayakan organ dan saluran respirasi untuk menyimpan udara sebanyak mungkin. Teknik pernapasan ini dapat berupa seperti thai chi, waitankung, yoga, mahatma, buteyko dan pranayama [9]. Diantara beberapa teknik pernapasan tersebut yang memang khusus untuk pasien asma ialah teknik pernapasan buteyko dan pranayama [9].Teknik pernapasan buteyko merupakan sebuah teknik napas yang dikembangkan oleh profesor berasal dari Rusia bernama Konstantin Buteyko, beliau menyakini bahwa penyebab utama dari asma menjadi kronis yaitu karena masalah hiperventilasi yang tersembunyi, dengan bernapas melalui hidung program dasar tersebut dapat memperlambat frekuensi napas agar menjadi normal, hal tersebut bisa pula memperbaiki pernapasan diafragma (dada) [4]. 


\section{Prosiding Seminar Nasional Kesehatan 2021 Lembaga Penelitian dan Pengabdian Masyarakat Universitas Muhammadiyah Pekajangan Pekalongan}

Penelitian Juwita \& Sary [4] di wilayah kerja Puskesmas Guguk Panjang Bukittinggi pada tahun 2018 tentang pernapasan buteyko bermanfaat dalam pengontrolan asma, menunjukkan bahwa terdapat kenaikan kontrol asma sesudah pemberian intervensi dibandingkan sebelum pemberian intervensi teknik pernpasan buteyko, sehingga dapat disimpulkan bahwa pernapasan buteyko bermanfaat dalam pengontrolan asma, hal ini disebabkan karena setelah dilakukan teknik pernapasan buteyko, jalan napas responden lebih terbuka sehingga oksigen bisa masuk secara maksimal ke paru-paru dan frekuensi napas responden menjadi stabil atau dalam batas normal. Berdasarkan latar belakang tersebut, maka peneliti tetarik untuk menyusun penelitian literature review ini dengan judul "Literature Review : Pengaruh Teknik Pernapasan Buteyko Terhadap Kontrol Asma".

\section{Metode}

Penelitian literature review ini menggunakan desain quasi eksperimen, dengan rancangan pre dan post test serta menggunakan alat pengukuran kontrol asma ACT (Asthma Control Test) dan ACQ (Asthma Control Quatinnare). Database pada penelitian ini menggunakan penelusuran melalui Garba Garuda, dan Researchgate, serta menggunakan dua bahasa dalam melakukan pencarian artikel yaitu bahasa Indonesia dan bahasa Inggris, untuk artikel berbahasa Indonesia menggunakan kata kunci : "Asma", "Buteyko", "Kontrol asma", sedangkan untuk artikel bahasa Inggris menggunakan kata kunci : "Asthma", "Buteyko", "Asthma control", artikel yang digunakan terbitan 10 tahun terakhir. Proses pencarian artikel dengan kata kunci tersebut pada Garba Garuda didapatkan artikel sebanyak 19 sedangkan pada Researchgate didapatkan artikel sebanyak 100, kemudian dilakukan seleksi berdasarkan judul, pada Garba Garuda didapatkan artikel sebanyak 6 sedangkan pada Researchgate sebanyak 16, setelah itu diidentifikasi kembali berdasarkan abstrak pada Garba Garudadidapatkan artikelsebanyak 4 sedangkan pada Researchgate sebanyak 7, dan terakhir diidentifikasi berdasarkan kriteria inklusi dan eksklusi serta telaah kritis didapatkan artikel pada Garba Garuda sebanyak 1, dan pada researchgate sebanyak 4 artikel.

Kriteria inklusi dan eksklusi yang digunakan dalam penelitian literature review ini dengan menggunakan format PICOTS (population, intervention, comparative group, outcome, time dan study design). Kriteria inklusi : (1) responden pada penelitian ini orang yang menderita asma, (2) intervensi yang digunakan yaitu teknik pernapasan buteyko, (3) tidak membandingkan intervensi teknik pernapasan buteyko dengan intervensi yang lainnya, (4) terdapat pengaruh pemberian teknik pernapasan buteyko dengan kontol asma, (5) intervensi dilakukan minimal dua minggu, (6) artikel yang diambil menggunakan design penelitian quasi eksperiment, dengan rancangan pre dan post test, sedangkan kriteria eksklusinya yaitu : (1) hasil artikel tidak terdapat pengaruh pemberian teknik pernapasan buteyko dengan kontrol asma, dan (2) penelitian bersifat non eksperimen. Instrumen telaah kritis dalam penelitian ini menggunakan the Joanna Briggs Institute (JBI) critical appraisal checklist for quasy eksperimental studies. Waktu penelitian ini dilakukan mulai dari bulan April-Juni 2021. 


\section{Prosiding Seminar Nasional Kesehatan Lembaga Penelitian dan Pengabdian Masyarakat Universitas Muhammadiyah Pekajangan Pekalongan}

\section{Hasil dan Pembahasan}

\section{Hasil}

1. Karakteristik responden

a. Jenis kelamin

Tabel 4.1 Karakteristik Responden Berdasarkan Jenis Kelamin

\begin{tabular}{|c|c|c|c|c|c|c|c|c|}
\hline \multicolumn{5}{|c|}{ Artikel } & \multicolumn{4}{|c|}{ Jenis Kelamin } \\
\hline \multirow[b]{2}{*}{ Penulis } & \multirow[b]{2}{*}{ Study } & \multirow[b]{2}{*}{ Publish } & \multirow[b]{2}{*}{ Lokasi } & \multirow[b]{2}{*}{$\begin{array}{r}\text { Sam } \\
\text { pel } \\
\text { (n) }\end{array}$} & \multicolumn{2}{|c|}{ Laki-laki } & \multicolumn{2}{|c|}{ Perempuan } \\
\hline & & & & & $\mathbf{F}$ & $\%$ & $\mathbf{F}$ & $\%$ \\
\hline Prasanna K.B, et al & 2013 & 2015 & India & 50 & 18 & 8,1 & 32 & 14,4 \\
\hline Wiwik Udayani, et al & NM & 2020 & Indonesia & 38 & 10 & 4,5 & 28 & 12,6 \\
\hline $\begin{array}{l}\text { Erna Melastuti \& Lailya } \\
\text { Husna }\end{array}$ & 2014 & 2015 & Indonesia & 34 & 14 & 6,3 & 20 & 9 \\
\hline $\begin{array}{l}\text { Eman Mahmoud hafez } \\
\text { Mohamed, et al }\end{array}$ & 2018 & 2018 & Mesir & 50 & 33 & 14,9 & 17 & 7,66 \\
\hline Yosreah Mohamed, et al & 2018-2019 & 2019 & Mesir & 50 & 38 & 17,1 & 12 & 5,41 \\
\hline \multicolumn{4}{|c|}{ Total masing-masing jenis kelamin } & 222 & 113 & 50,9 & 109 & 49,1 \\
\hline Total responden (n) & & & & & & 222 & $100 \%)$ & \\
\hline
\end{tabular}

Berdasarkan hasil literature review pada lima artikel didapatkan data bahwa terdapat dua jenis kelamin responden yaitu berjenis kelamin laki-laki dan perempuan. Jumlah jenis kelamin laki-laki sebanyak $113(50,9 \%)$ responden, sedangkan jumlah kelamin perempuan sebanyak $109(49,1 \%)$ responden. Maka dapat disimpulkan bahwa responden berjenis kelamin laki-laki lebih banyak dibandingkan dengan berjenis kelamin perempuan.

b. Usia responden

4.2 Tabel Karakteristik Responden Berdasarkan Usia

\begin{tabular}{|c|c|c|c|c|c|c|}
\hline \multicolumn{4}{|c|}{ Artikel } & \multicolumn{3}{|c|}{ Karakteristik Usia } \\
\hline \multirow[b]{2}{*}{ Penulis } & \multirow[b]{2}{*}{ Study } & \multirow[b]{2}{*}{ Publish } & \multirow[b]{2}{*}{ Lokasi } & \multirow[b]{2}{*}{ Usia } & \multicolumn{2}{|c|}{ Jumlah } \\
\hline & & & & & $\mathbf{F}$ & $\%$ \\
\hline Prasanna K.B, et al & 2013 & 2015 & India & $25-60$ tahun & 50 & 22,52 \\
\hline \multirow[t]{4}{*}{ Wiwik Udayani, et al } & NM & 2020 & Indonesia & 18-25 tahun & 1 & 0,45 \\
\hline & & & & 26-35 tahun & 9 & 4,05 \\
\hline & & & & $36-45$ tahun & 15 & 6,75 \\
\hline & & & & $\begin{array}{l}46-55 \text { tahun } \\
56-60 \text { tahun }\end{array}$ & $\begin{array}{c}10 \\
3\end{array}$ & $\begin{array}{r}4,5 \\
1,35\end{array}$ \\
\hline \multirow{2}{*}{$\begin{array}{l}\text { Erna Melastuti \& Lailya } \\
\text { Husna }\end{array}$} & 2014 & 2015 & Indonesia & 26-45 tahun & 9 & 4,05 \\
\hline & & & & $\begin{array}{l}46-65 \text { tahun } \\
>66 \text { tahun }\end{array}$ & $\begin{array}{c}22 \\
3\end{array}$ & $\begin{array}{r}9,9 \\
1,35\end{array}$ \\
\hline \multirow{4}{*}{$\begin{array}{l}\text { Eman Mahmoud hafez } \\
\text { Mohamed, et al }\end{array}$} & 2018 & 2018 & Mesir & $<35$ tahun & 8 & 3,6 \\
\hline & & & & 35-44 tahun & 8 & 3,6 \\
\hline & & & & 45-54 tahun & 18 & 8,1 \\
\hline & & & & 55-65 tahun & 16 & 7,2 \\
\hline \multirow{3}{*}{$\begin{array}{l}\text { Yosreah Mohamed, et } \\
\text { al }\end{array}$} & 2018 & 2019 & Mesir & $<40$ tahun & 12 & 5,4 \\
\hline & & & & 40-50 tahun & 9 & 4,05 \\
\hline & & & & $>50$ tahun & 29 & 13,06 \\
\hline \multicolumn{3}{|c|}{ Total responden $(\mathrm{n})$} & & & 222 & 100 \\
\hline
\end{tabular}

Hasil literature review terhadap lima artikel didapatkan data bahwa berdasarkan karakteristik umur, paling banyak responden berusia 25-60 tahun $(22,52 \%)$, hal ini ditemukan pada penelitian Prasanna K.B, et al [10]. 


\section{Prosiding Seminar Nasional Kesehatan Lembaga Penelitian dan Pengabdian Masyarakat Universitas Muhammadiyah Pekajangan Pekalongan}

c. Pekerjaan responden

Tabel 4.3Karakteristik Responden Berdasarkan Pekerjaan

\begin{tabular}{|c|c|c|c|c|c|c|}
\hline \multicolumn{3}{|c|}{ Artikel } & \multicolumn{4}{|c|}{ Jenis Pekerjaan } \\
\hline \multirow[t]{2}{*}{ Penulis } & \multirow[t]{2}{*}{ Publish } & \multirow[t]{2}{*}{ Lokasi } & \multicolumn{2}{|c|}{$\begin{array}{c}\text { Ibu } \\
\text { RT / tidak } \\
\text { bekerja }\end{array}$} & \multicolumn{2}{|c|}{ Bekerja } \\
\hline & & & $\mathbf{F}$ & $\%$ & $F$ & $\%$ \\
\hline Prasanna K.B, et al & 2015 & India & NM & NM & NM & NM \\
\hline Wiwik Udayani, et al & 2020 & Indonesia & 7 & 4,06 & 31 & 18 \\
\hline $\begin{array}{l}\text { Erna Melastuti \& Lailya } \\
\text { Husna }\end{array}$ & 2015 & Indonesia & 10 & 5,8 & 24 & 13,95 \\
\hline $\begin{array}{l}\text { Eman Mahmoud hafez } \\
\text { Mohamed, et al }\end{array}$ & 2018 & Mesir & 6 & 3,5 & 44 & 25,6 \\
\hline Yosreah Mohamed, et al & 2019 & Mesir & 17 & 9,9 & 33 & 19,19 \\
\hline \multicolumn{3}{|c|}{ Total masing-masing pekerjaan } & 40 & 23,26 & 132 & 76,74 \\
\hline \multicolumn{3}{|l|}{ Total responden (n) } & \multicolumn{4}{|c|}{$172(100 \%)$} \\
\hline
\end{tabular}

Hasil literature review terhadap lima artikel didapatkan data bahwa terdapat dua jenis pekerjaan yaitu diantaranya ; sebagai ibu rumah tangga atau tidak bekerja sebanyak $40(23,26 \%)$ responden, dan bekerja sebanyak 132 $(76,74 \%)$ responden. Maka dari data tersebut dapat disimpulkan bahwa paling banyak responden mempunyai pekerjaan, dibandingkan dengan ibu rumah tangga atau tidak bekerja.

d. Tingkat pendidikan responden

Tabel 4.4Karakteristik Responden Berdasarakan Tingkat Pendidikan

\begin{tabular}{|c|c|c|c|c|c|c|c|c|}
\hline \multicolumn{4}{|c|}{ Artikel } & \multicolumn{5}{|c|}{ Tingkat Pendidikan } \\
\hline Penulis & $\begin{array}{l}\text { Stu } \\
\text { dy }\end{array}$ & $\begin{array}{l}\text { Publi } \\
\text { sh }\end{array}$ & Lokasi & $\begin{array}{l}\text { Buta huruf/ } \\
\text { tdk sekolah }\end{array}$ & SD & SMP & SMA & PT \\
\hline Prasanna K.B, et al & 2013 & 2015 & India & NM & NM & NM & NM & NM \\
\hline Wiwik Udayani, et al & NM & 2020 & Indonesia & NM & NM & 3 & 13 & 22 \\
\hline $\begin{array}{l}\text { Erna Melastuti \& Lailya } \\
\text { Husna }\end{array}$ & 2014 & 2015 & Indonesia & NM & 2 & 11 & 20 & 1 \\
\hline $\begin{array}{l}\text { Eman Mahmoud hafez } \\
\text { Mohamed, et al }\end{array}$ & 2018 & 2018 & Mesir & 10 & 7 & 25 & NM & 8 \\
\hline $\begin{array}{l}\text { Yosreah Mohamed, et } \\
\text { al }\end{array}$ & 2018 & 2019 & Mesir & 18 & 6 & 6 & NM & 20 \\
\hline \multicolumn{4}{|c|}{ Total masing-masing tingkat pendidikan } & $\begin{array}{c}28 / \\
16,28\end{array}$ & $\begin{array}{l}15 / \\
8,7\end{array}$ & $\begin{array}{c}45 / \\
26,1 \\
6\end{array}$ & $\begin{array}{l}33 / \\
19,2\end{array}$ & $\begin{array}{l}51 / \\
29, \\
65\end{array}$ \\
\hline Total responden (n) & & & & \multicolumn{5}{|c|}{$172(100 \%)$} \\
\hline
\end{tabular}

Hasil literature review terhadap lima artikeldidapatkan data bahwa terdapat lima kelompok berdasarkan tingkat pendidikan yaitu buta huruf/tidak sekolah, SD, SMP, SMA, PT (Perguruan Tinggi). Jumlah responden yang buta huruf 


\section{Prosiding Seminar Nasional Kesehatan Lembaga Penelitian dan Pengabdian Masyarakat Universitas Muhammadiyah Pekajangan Pekalongan}

sebanyak $28(16,28 \%)$, SD sebanyak $15(8,7 \%)$, SMP sebanyak $45(26,16 \%)$, SMA sebanyak 33 (19,2\%), dan PT 51 (29,65\%). Maka dapat disimpulkan bahwa paling banyak responden memiliki tingkat pendidikan PT, dibandingkan tingkat pendidikan yang lainnya.

2. Tingkat Kontrol Asma sebelum dan sesudah pemberian teknik pernpasan buteyko a. Tingkat kontrol asma sebelum pemberian teknik pernapasan buteyko

Tabel 4.5Artikel Berdasarkan Tingkat Kontrol Asma Sebelum Pemberian Teknik Pernapasan Buteyko

\begin{tabular}{|c|c|c|c|c|c|c|c|c|c|}
\hline \multicolumn{4}{|c|}{ Artikel } & \multicolumn{6}{|c|}{ Tingkat Kontrol Asma } \\
\hline \multirow[t]{2}{*}{ Penulis } & \multirow{2}{*}{$\begin{array}{l}\text { Stu } \\
\text { dy }\end{array}$} & \multirow{2}{*}{$\begin{array}{l}\text { Publi } \\
\text { sh }\end{array}$} & \multirow[t]{2}{*}{ Lokasi } & \multicolumn{2}{|c|}{$\begin{array}{c}\text { Tidak } \\
\text { Terkontrol }\end{array}$} & \multicolumn{2}{|c|}{$\begin{array}{l}\text { Terkontrol } \\
\text { sebagian }\end{array}$} & \multicolumn{2}{|c|}{$\begin{array}{l}\text { Terkontrol } \\
\text { total }\end{array}$} \\
\hline & & & & $\mathbf{F}$ & $\%$ & $\mathbf{F}$ & $\%$ & $\mathbf{F}$ & $\%$ \\
\hline Prasanna K.B, etal & 2013 & 2015 & India & 38 & 24,5 & 12 & 7,74 & 0 & $0 \%$ \\
\hline Wiwik Udayani, et al & NM & 2020 & Indonesia & 28 & 18,06 & 10 & 6,45 & 0 & $0 \%$ \\
\hline $\begin{array}{l}\text { Erna Melastuti \& Lailya } \\
\text { Husna }\end{array}$ & 2014 & 2015 & Indonesia & 4 & 2,6 & 13 & 8,4 & 0 & $0 \%$ \\
\hline $\begin{array}{l}\text { Eman Mahmoud hafez } \\
\text { Mohamed, et al }\end{array}$ & 2018 & 2018 & Mesir & 22 & 14,19 & 28 & 18,06 & 0 & $0 \%$ \\
\hline $\begin{array}{l}\text { Yosreah Mohamed, Sabah } \\
\text { Elderiny \& Dr. Lobna } \\
\text { Ibrahim }\end{array}$ & 2018 & 2019 & Mesir & NM & NM & NM & NM & NM & NM \\
\hline \multicolumn{4}{|c|}{$\begin{array}{l}\text { Total masing-masing tingkat kontrol asma sebelum } \\
\text { pemberian teknik pernapasan buteyko }\end{array}$} & 92 & 59,35 & 63 & 40,65 & 0 & $0 \%$ \\
\hline \multicolumn{4}{|c|}{$\begin{array}{c}\text { pemberlan teknIK pernapasan buteyko } \\
\text { Total responden }(\mathrm{n}) \\
\end{array}$} & & \multicolumn{5}{|c|}{$155(100 \%)$} \\
\hline
\end{tabular}

Hasil literature review terhadap lima artikel didapatkan data bahwa terdapat tiga tingkat kontrol asma yaitu ; tidak terkontrol, terkontrol sebagian, dan terkontrol total. Jumlah tidak terkontrol sebanyak $92 \quad$ (59,35\%), terkontrol sebagian sebanyak $63(40,65 \%)$ dan terkontrol total sebanyak $0 \quad(0 \%)$. Maka dapat disimpulkan bahwa berdasarkan tingkat kontrol asma sebelum pemberian teknik pernapasan buteyko, paling banyak tingkat kontrol asma pada tingkat tidak terkontrol, dan tidak ada responden yang terkontrol total.

b. Tingkat kontrol asma sesudah pemberian teknik pernapasan buteyko

Tingkat kontrol asma sesudah pemberian teknik pernapasan buteyko dapat dilihat pada tabel 4.6.

Tabel 4.6Artikel Berdasarkan Tingkat Kontrol Asma Sesudah Pemberian Teknik

\begin{tabular}{|c|c|c|c|c|c|c|c|c|c|}
\hline \multicolumn{10}{|c|}{ Pernapasan Buteyko } \\
\hline \multicolumn{4}{|c|}{ Artikel } & & \multicolumn{5}{|c|}{ Tingkat Kontrol Asma } \\
\hline \multirow[t]{2}{*}{ Penulis } & \multirow[t]{2}{*}{ Study } & \multirow[t]{2}{*}{ Publish } & \multirow[t]{2}{*}{ Lokasi } & \multicolumn{2}{|c|}{$\begin{array}{c}\text { Tidak } \\
\text { Terkontrol }\end{array}$} & \multicolumn{2}{|c|}{$\begin{array}{c}\text { Terkontrol } \\
\text { sebagian }\end{array}$} & \multicolumn{2}{|c|}{$\begin{array}{c}\text { Terkontrol } \\
\text { total }\end{array}$} \\
\hline & & & & $\mathbf{F}$ & $\%$ & $\mathbf{F}$ & $\%$ & $\mathbf{F}$ & $\%$ \\
\hline Prasanna K.B, etal & 2013 & 2015 & India & 2 & 0,98 & 19 & 9,27 & 29 & 14,15 \\
\hline Wiwik Udayani, et al & NM & 2020 & Indonesia & 15 & 7,32 & 13 & 6,34 & 10 & 4,88 \\
\hline $\begin{array}{l}\text { Erna Melastuti \& Lailya } \\
\text { Husna }\end{array}$ & 2014 & 2015 & Indonesia & 2 & 0,98 & 15 & 7,32 & 0 & 0 \\
\hline $\begin{array}{l}\text { Eman Mahmoud hafez } \\
\text { Mohamed, et al }\end{array}$ & 2018 & 2018 & Mesir & 2 & 0,98 & 22 & 10,73 & 26 & 12,68 \\
\hline Yosreah Mohamed, et al & 2018 & 2019 & Mesir & 14 & 6,8 & 8 & 3,9 & 28 & 13,66 \\
\hline \multicolumn{4}{|c|}{$\begin{array}{l}\text { Total masing-masing tingkat kontrol asma sesudah } \\
\text { pemberian teknik pernapasan buteyko }\end{array}$} & 35 & 17,06 & 77 & 37,56 & 93 & 45,37 \\
\hline \multicolumn{4}{|c|}{ Total responden (n) } & & \multicolumn{5}{|c|}{$205(100 \%)$} \\
\hline
\end{tabular}




\section{Prosiding Seminar Nasional Kesehatan 2021 Lembaga Penelitian dan Pengabdian Masyarakat Universitas Muhammadiyah Pekajangan Pekalongan}

Hasil literature review terhadap lima artikel didapatkan data bahwa terdapat tiga tingkat kontrol asma yaitu ; tidak terkontrol, terkontrol sebagian, dan terkontrol total. Jumlah tidak terkontrol sebanyak $35(17,06 \%)$, terkontrol sebagian sebanyak $77(37,56 \%)$ dan terkontrol total sebanyak 93 (45,37\%). Maka dapat disimpulkan bahwa berdasarkan tingkat kontrol asma sesudah pemberian teknik pernapasan buteyko, paling banyak tingkat kontrol asma pada tingkat terkontrol total.

3. Pengaruh Teknik Pernapasan ButeykoTerhadap Kontrol Asma

Tabel 4.7 Artikel Berdasarkan Pengaruh Teknik Pernapasan Buteyko Terhadap Kontrol Asma

\begin{tabular}{|c|c|c|c|c|c|}
\hline \multicolumn{3}{|c|}{ Artikel } & \multirow[t]{2}{*}{ Durasi } & Outcome & \multirow{2}{*}{$\begin{array}{c}U_{j i} \\
\text { Statistik }\end{array}$} \\
\hline Penulis & Publish & Lokasi & & P value & \\
\hline $\begin{array}{l}\text { Prasanna } \\
\text { K.B, etal }\end{array}$ & 2013 & India & $\begin{array}{l}\text { Penelitian dilakukan selama dua bulan, } \\
\text { intervensinya dilakukan dua kali dalam } \\
\text { sehari (pagi, sore). Tindak lanjut rutin } \\
\text { dilakukan melalui panggilan telepon } \\
\text { yang sering, juga para peserta diminta } \\
\text { untuk mengunjungi rumah sakit setiap } \\
\text { mingqu sekali. }\end{array}$ & $<0,05$ & ChiSquare \\
\hline $\begin{array}{l}\text { Winvik } \\
\text { Udayani, et } \\
\text { al }\end{array}$ & 2020 & Indonesia & $\begin{array}{l}\text { Latihan teknik pernapasan buteyko } \\
\text { dilakukan selama } 15 \text { menit, latihan } \\
\text { dilakukan } 3 x \text { seminggu selama } 8 \\
\text { minggu. }\end{array}$ & 0,000 & $\begin{array}{l}\text { GLM-RM } \\
\text { (General } \\
\text { Linear } \\
\text { Model- } \\
\text { Repeated } \\
\text { Measure) }\end{array}$ \\
\hline $\begin{array}{l}\text { Erna } \\
\text { Melastuti \& } \\
\text { Lailya Husna }\end{array}$ & 2015 & Indonesia & NM & 0,000 & $\begin{array}{l}\text { Paired } \\
\text { Sample T- } \\
\text { Test }\end{array}$ \\
\hline $\begin{array}{l}\text { Eman } \\
\text { Mahmoud } \\
\text { hafez } \\
\text { Mohamed, et } \\
\text { al }\end{array}$ & 2018 & Mesir & $\begin{array}{l}\text { Setiap pasien dilatih dengan teknik } \\
\text { pernapasan buteykodua kali } \\
\text { semingggu, dan sesi sekitar ( } 20 \text { menit). } \\
\text { Minggu pertama setiap pasien } \\
\text { kelompok ini dilatih teknik pernapasan } \\
\text { buteykosecara intensif selama } 4 \text { hari } \\
\text { kemudian } 3 \text { minggu berikutnya } \\
\text { sebanyak } 2 \text { sesi perminggu. }\end{array}$ & 0,000 & ChiSquare \\
\hline $\begin{array}{l}\text { Yosreah } \\
\text { Mohamed, et } \\
\text { al }\end{array}$ & 2019 & Mesir & $\begin{array}{l}\text { Waktu sesi intervensinya di pagi hari } \\
\text { setidaknya dua jam setelah makan. } \\
\text { Setiap pasien diminta untuk melakukan } \\
\text { BBt di rumah dua kali sehari pada pagi } \\
\text { dan sore hari, minimal } 2 \text { jam setelah } \\
\text { makan selama satu bulan setelah } \\
\text { pasien melakukan pelatihan BBT. }\end{array}$ & 0,017 & ChiSquare \\
\hline
\end{tabular}

Hasil literature review terhadap lima artikel berdasarkan pengaruh teknik pernapasan buteyko terhadap kontrol asma didapatkan hasil $\mathrm{p}$ value dari ke lima artikel tersebut $<0,05$, maka dapat disimpulkan bahwa tingkat kontrol asma sesudah pemberian teknik pernapasan buteyko mengalami perbaikan, sehingga teknik pernafasan buteykoberpengaruh terhadap tingkat kontrol asma pada penderita asma.

\section{Pembahasan}

1. Karakteristik Responden

Berdasarkan analisa data yang dilakukan ke lima artikel didapatkan penggolongan karakteristik responden yaitu diantaranya jenis kelamin, usia, pekerjaan, dan tingkat pendidikan. 


\section{Prosiding Seminar Nasional Kesehatan 2021 Lembaga Penelitian dan Pengabdian Masyarakat Universitas Muhammadiyah Pekajangan Pekalongan}

a. Karakteristik responden berdasarkan jenis kelamin

Berdasarkan karakteristik jenis kelamin responden dari lima artikel yang direview paling banyak responden berjenis kelamin laki-laki dibandingkan dengan perempuan. Hal ini sejalan dengan penelitian Astuti \& Darliana [11] serta penelitian yang lainnya pada Maskhanah et al [12] yang menyatakan bahwa paling banyak asma diderita oleh laki-laki dibandingkan perempuan. $\mathrm{Hal}$ ini di sebabkan karena laki-laki cenderung memiliki beban kerja yang lebih berat, gaya hidup yang tidak tepat. Selain itu, kebiasaan merokok yang didominasi oleh laki-laki yang juga dapat memicu terjadinya penyakit asma [11].

b. Karakteristik responden berdasarkan usia

Berdasarkan karakteristik usia responden dari lima artikel yang direview paling banyak responden berusia 25-60 tahun dibandingkan dengan usia yang lainnya. Hal ini sejalan dengan penelitian yang dilakukan oleh Loriana [13] yang menyatakan bahwa berdasarkan karakteristik usia responden didapatkan data paling banyak berusia 26-45 tahun, dan pada penelitian Siswanti [2] juga menyebutkan bahwa paling banyak responden berusia 46-55 tahun dibandingkan dengan rentang usia yang lainnya. Menurut Astuti \& Darliana [11] menyatakan bahwa dengan meningkatnya usia maka akan terjadi penurunan fungsi paru dan peradangan jalan napas, hal ini diakibatkan karena hiperreaktivitas bronkus terhadap alergen.

c. Karakteristik responden berdasarkan jenis pekerjaan

Berdasarkan karakteristik jenis pekerjaan responden dari lima artikel yang direview paling banyak responden memiliki pekerjaan dibandingkan tidak bekerja, hal ini sejalan dengan penelitian yang dilakukan oleh Udayani et al [14] presentase penderita asma berdasarkan jenis pekerjaannya paling banyak memiliki pekerjaan. Pada responden yang bekerja banyak faktor pemicu yang dapat menimbulkan asma beberapa contohnya dikarenakan oleh pengaruh lingkungan kerja, bahan kimia, dan juga stres [15]. Responden yang bekerja akan memiliki beban kerja yang kerap kali membuat stres pada mereka, dan hal ini dapat menjadi pencetus asma pada beberapa individu, selain itu juga bisa memperberat serangan asma yang sudah ada [16].

d. Karakteristik responden berdasarkan tingkat pendidikan

Berdasarkan karakteristik tingkat pendidikan responden dari lima artikel yang direview paling banyak responden memiliki tingkat pendidikan perguruan tinggi (PT), dibandingkan dengan tingkat pendidikan yang lainnya, hal ini sejalan dengan dengan penelitian Udayani et al [14] yang menyatakan bahwa tingkat pendidikan responden paling banyak yaitu Perguran Tinggi (PT) dibandingkan dengan tingkat pendidikan yang lainnya. Pendidikan mempengaruhi sikap, tindakan, pemikiran seseorang, dimana setiap orang yang biasanya memiliki pendidikan dasar, menengah maupun atas, masingmasing memiliki karakteristik yang berbeda. Hal tersebut dikarenakan pendidikan akan mempengaruhi pola pikir, semakin tinggi pendidikan biasanya 


\section{Prosiding Seminar Nasional Kesehatan 2021 Lembaga Penelitian dan Pengabdian Masyarakat Universitas Muhammadiyah Pekajangan Pekalongan}

akan semakin baik pemikiran maupun tingkah laku. Pola pikir yang dihasilkan dari ilmu pengetahuan yang didapat dari pendidikan akan berdampak pada perbuatan, sikap, tindakan. Hal ini menunjukkan bahwa orang dengan pendidikan yang lebih tinggi cenderung lebih peduli terhadap kesehatan pribadi [17].

2. Tingkat kontrol asma sebelum dan sesudah dilakukan teknik pernapasan buteyko

Tingkat kontrol asma sebelum dan sesudah dilakukan teknik pernapasan buteyko terhadap kontrol asma, didapatkan data bahwa sebelum pemberian intervensi paling banyak responden tidak terkontrol, sedangkan setelah pemberian intervensi responden paling banyak pada kontrol total. Hal ini menunjukkan bahwa adanya kenaikan jumlah responden pada tingkat kontrol total setelah pemberian intervensi. Hal ini sejalan dengan penelitian yang dilakukan oleh K.B. et al [10] dan Mohamed et al [18] yang menyatakan bahwa setelah dilakukan pemberian intervensi teknik pernapasan buteyko, paling banyak jumlah responden pada tingkat kontrol total dibandingkan dengan jumlah responden tidak terkontrol dan terkontrol sebagian.

3. Pengaruh Teknik Pernapasan Buteyko Terhadap Kontrol asma

Dari lima artikel berdasarkan pengaruh teknik pernapasan buteyko terhadap kontrol asma dapat disimpulkan bahwa tingkat kontrol asma sesudah pemberian teknik pernapasan buteykomengalami perbaikan, sehingga teknik pernafasan buteykoberpengaruh terhadap tingkat kontrol asma pada penderita asma. Hal ini sejalan dengan penelitian yang dilakukan Prem et al [19] tentang comparison of the effects of buteyko and pranayama breathing techniques on quality of life in patients with asthma - a randomized controlled trial, didapatkan hasil bahwa pasca intervensi, kelompok buteyko menunjukkan tren perbaikan yang lebih baik dalam total skor kuesioner kualitas hidup asma daripada pranayama dan kontrol kelompok, sehingga dapat disimpulkan bahwa kelompok buteyko menunjukkan tren peningkatan kualitas hidup dan pengendalian asma yang lebih baik daripada kelompok yang melakukan latihan pernapasan pranayama.

Penelitian pada Juwita \& Sary [4], serta Firdaus \& Wahyuni [9] juga menyatakan bahwa teknik pernapasan buteyko dapat mengontrol asma.Ketika terjadi serangan asma, penderita asma bernapas dua kali lebih cepat dibandingkan dengan orang yang normal (hiperventilasi) [20]. Teori yang mendasari buteyko dalam mengembangkan teknik pernapasan ini adalah : apabila penderita asma melakukan pernapasan dalam, maka jumlah $\mathrm{CO}_{2}$ yang dikeluarkan akan semakin meningkat. Perihal ini bisa menimbulkan jumlah $\mathrm{CO}_{2}$ di paru-paru, darah dan jaringan akan menjadi berkurang [20].

Terjadinya defisiensi $\mathrm{CO}_{2}$ diakibatkan oleh metode bernapas dalam yang bisa menimbulkan $\mathrm{pH}$ darah menjadi alkalis. Perubahan $\mathrm{pH}$ bisa mengganggu keseimbangan protein, vitamin dan proses metabolisme. Apabila $\mathrm{pH}$ mencapai nilai 8, maka hal ini bisa menimbulkan gangguan metabolik yang parah [20]. Terjadinya defisiensi $\mathrm{CO}_{2}$ menyebabkan spasme pada otot polos bronkus, kejang pada otak, pembuluh darah, spastik usus, saluran empedu dan organ yang 


\section{Prosiding Seminar Nasional Kesehatan 2021 Lembaga Penelitian dan Pengabdian Masyarakat Universitas Muhammadiyah Pekajangan Pekalongan}

lainnya. Apabila penderita asma bernapas dalam, maka semakin sedikit jumlah oksigen yang mencapai otak, jantung, ginjal serta organ yang lain yang menimbulkan hipoksia disertai hipertensi arteri [20]. Kekurangan $\mathrm{CO}_{2}$ pada organ-organ vital (termasuk otak) dan sel-sel saraf meningkat, stimulasi terhadap pusat pengendalian respirasi di otak yang memunculkan rangsangan untuk bernapas, serta lebih lanjut meningkatkan pernapasan sehingga proses bernapas lebih intensif (hiperventilasi ataupun over breathing) [20]. Over breathing bisa menimbulkan ketidakseimbangan kadar $\mathrm{CO}_{2}$ di dalam tubuh (terutama paru-paru dan sirkulasi) sehingga perihal ini mengubah kadar $\mathrm{O}_{2}$ darah dan menurunkan kadar $\mathrm{O}_{2}$ seluler. Keseimbangan asam-basa tubuh juga dipengaruhi oleh pola pernapasan dan konsentrasi $\mathrm{O}_{2}$ serta $\mathrm{CO}_{2}$. Pada waktu serangan, over breathing bisa menimbulkan stres pada tubuh [20].

Konsep metode buteykoini berupaya untuk mengatasi permasalahan penurunan kandungan $\mathrm{CO}_{2}$ tersebut supaya kembali pada kadar yang normal. Perihal inilah yang akhirnya menimbulkan relaksasi otot polos pada dinding bronkus dengan demikian menghindari bronkospasme dan membuka jalan napas serta mencegah terjadinya serangan asma [20]. Bagaimanapun menurut pemahaman metode buteyko, obat hanya menangani gejala saja, sehingga bila pengobatan dihentikan maka akan timbul kembali. Konsep metode buteyko inilah yang mengatasi secara alami terhadap defisiensi kadar $\mathrm{CO}_{2}$ dalam alveoli [20].

\section{Kesimpulan}

Tingkat kontrol asma mengalami kenaikan ataupun perbaikan setelah pemberian intervensi teknik pernapasan buteyko, dibandingkan sebelum pemberian intervensi, serta teknik pernapasan buteyko ini memiliki pengaruh dalam mengontrol asma dengan hasil $p$ value $<0,05$.

\section{Referensi}

[1] A. H. Nurarif and H. Kusuma, Aplikasi Asuhan Keperawatan Berdasarkan Diagnosa Medis \& Nanda NIC- NOC. Jilid 1. Jogjakarta: Mediaction, 2015.

[2] H. Siswanti, "Efektifitas Pemberian Teknik Pernapasan Buteyko terhadap Kekambuhan pada Pasien Asma," Proceeding of The URECOL, pp. 796-801, 2019.

[3] GINA, "Pocket Guide For Asthma Management And Prevention (For Adults and Children Older Than 5 Years)," 2020, [Online]. Available: https://ginasthma.org/wp-content/uploads/2020/04/Main-pocketguide20200403-final-wms.pdf.

[4] L. Juwita and I. P. Sary, "Pernafasan Buteyko Bermanfaat Dalam Pengontrolan Asma," Real Nurs. J., vol. 2, no. 1, pp. 10-20, 2019.

[5] D. Kartikasari and N. N. Fajriyah, "Latihan Napas Dalam terhadap Peningkatan Arus Puncak Ekspirasi ( Ape ) Pasien Asma Di Balai Kesehatan Paru Masyarakat Kota Pekalongan," vol. 14, no. 02, pp. 113-117, 2019, [Online]. Available: 


\section{Prosiding Seminar Nasional Kesehatan 2021 Lembaga Penelitian dan Pengabdian Masyarakat Universitas Muhammadiyah Pekajangan Pekalongan}

http://ojs.stikesmukla.ac.id/index.php/motor/article/view/27.

[6] D. Kartikasari and N. N. Fajriyah, "Edukasi Latihan Pernapasan Diafragma pada Pasien Asma di Poli Paru Rumah Sakit PKU Muhammadiyah Gamping Yogyakarta", pp. 1050-1053, 2019.

[7] D. Kartikasari, I. M. Jenie, and Y. Primanda, "Latihan Pernapasan Diafragma Meningkatkan Arus Puncak Ekspirasi (Ape) Dan Menurunkan Frekuensi Kekambuhan Pasien Asma," J. Keperawatan Indones., vol. 22, no. 1, pp. 53-64, 2019, doi: 10.7454/jki.v22i1.691.

[8] I. Baroroh, Hermansyah, and Septiyanti, "Pengaruh Teknik Pernafasan Buteyko Terhadap Penurunan Frekuensi Kekambuhan Asma Pada Pasien Penderita Asma," J. Media Kesehat., vol. 7, no. 2, pp. 124-129, 2014, doi: 10.33088/jmk.v7i2.235.

[9] A. Firdaus and N. T. Wahyuni, "Pengaruh Teknik Pernapasan Buteyko Terhadap Tingkat Kontrol Asma Pada Penderita Asma," J. Kesehat., vol. 8, no. 2, pp. 961966, 2017, doi: 10.38165/jk.v8i2.104.

[10] P. K.B., S. K.R., and D. C.M., "Effect of Buteyko breathing exercise in newly diagnosed asthmatic patients," vol. 5, no. 1, pp. 1-5, 2015, doi: 10.4103/22308598.151267.

[11] R. Astuti and D. Darliana, "The Reletionship Between Patients' Knowledge and Their Effort to Prevent the Bronchial Asthma," Idea Nurs. J., vol. IX, no. 1, pp. 9-15, 2018.

[12] Maskhanah et al, "Pengaruh Teknik Pernapasan Buteyko Terhadap Kekambuhan Asma Bronkhial," vol. 2, no. 6, pp. 254-262, 2019.

[13] R. Loriana, "Kombinasi Latihan Senam Asma Disertai Teknik Pernafasan Buteyko Eefektif Menurunkan Kekambuhan Asma," J. Citra Keperawatan, vol. 6, no. 2, pp. 67-70, 2018.

[14] W. Udayani, M. Amin, and M. Makhfudli, "Pengaruh Kombinasi Teknik Pernapasan Buteyko Dan Latihan Berjalan Terhadap Kontrol Asma Pada Pasien Asma Dewasa," J. IIm. Keperawatan (Scientific J. Nursing), vol. 6, no. 1, pp. 612, 2020, doi: 10.33023/jikep.v6i1.331.

[15] R. E. Kapti and N. Azizah, Perawatan Anak Sakit Di Rumah. Malang: UB Press, 2017.

[16] S. Embuai, "Riwayat Genetik, Asap Rokok, Keberadaan Debu, dan Stress Berhubungan dengan Kejadian Asma Bronkial," Moluccas Heal. J., vol. 2, no. April, pp. 11-18, 2020.

[17] D. H. Putri, "Hubungan Antara Tingkat Pengetahuan Mengenai Asma Terhadap Tingkat Kontrol Asma Pada Pasien Asma di Unit Pengobatan Penyakit Paru-Paru (UP4) Pontianak," pp. 1-17, 2016.

[18] E. M. H. Mohamed, A. A. M. ELmetwaly, and A. M. Ibrahim, "Buteyko Breathing Technique: A Golden Cure for Asthma," Am. J. Nurs. Res., vol. 6, no. 6, pp. 616-624, 2018, doi: 10.12691/ajnr-6-6-32. 
[19] V. Prem, R. C. Sahoo, and P. Adhikari, "Comparison of the effects of Buteyko and pranayama breathing techniques on quality of life in patients with asthma a randomized controlled trial," vol. 27, no. 2, pp. 133-141, 2012, doi: $10.1177 / 0269215512450521$.

[20] Nurdiansyah, "Pengaruh Teknik Pernapasan Buteyko Terhadap Penurunan Gejala Pasien Asma Kota Tangerang Selatan," 2013. 